\title{
Performing innovative business activity in sport in the Polish regulatory system
}

\section{Szymon Gajda}

Chair of Physical Education and Social Sciences, Department of Management and Marketing, Gdansk University of Physical Education and Sport, Gdansk, Poland

\section{abstract}

Innovation is widely recognized as necessary feature of progress in various areas of economy. It has also been supported by the EU and its Member States, including Poland. However, in the sport industry it has been visibly less exploited so far to achieve a market value. Literature quoted, hard and soft law documents legal analysis was performed. Although there are many existing examples of innovation provided by sport entrepreneurs, the regulatory system, by unclear regulations related to the most profitable kinds of innovation in sport, does not provide them equal stimulus as in other trade sectors. This study shows lack of sufficient regulatory support to innovation in sport commercial activity in Poland.

Key words: start-up, innovation in sport, commercial activity in sport.

\section{article details}

Article statistics: Word count: 3,763; Tables: 0; Figures: 0; References: 9

Received: June 2020; Accepted: August 2020; Published: November 2020

Full-text PDF: http://www.balticsportscience.com

Copyright @) Gdansk University of Physical Education and Sport, Poland

Indexation: Celdes, Clarivate Analytics Emerging Sources Citation Index (ESCl), CNKI Scholar (China National Knowledge Infrastructure), CNPIEC, De Gruyter - IBR (International Bibliography of Reviews of Scholarly Literature in the Humanities and Social Sciences), De Gruyter - IBZ (International Bibliography of Periodical Literature in the Humanities and Social Sciences), DOAJ, EBSCO - Central \& Eastern European Academic Source, EBSCO - SPORTDiscus, EBSCO Discovery Service, Google Scholar, Index Copernicus, J-Gate, Naviga (Softweco, Primo Central (ExLibris), ProQuest - Family Health, ProQuest - Health \& Medical Complete, ProQuest - Illustrata: Health Sciences, ProQuest - Nursing \& Allied Health Source, Summon (Serials Solutions/ProQuest, TDOne (TDNet), Ulrich's Periodicals Directory/ulrichsweb, WorldCat (OCLC)

Funding: This research received no specific grant from any funding agency in the public, commercial, or not-for-profit sectors.

Conflict of interests: Author has declared that no competing interest exists.

Corresponding author: Szymon Gajda, Gdansk University of Physical Education and Sport, Gorskiego 1 Str. 80-331 Gdansk, Poland; e-mail: szymon.gajda@awf.gda.pl

Open Access License: This is an open access article distributed under the terms of the Creative Commons Attribution-Non-Commercial-NoDerivatives 4.0 International (https://creativecommons.org/licenses/by-nc-nd/4.0/), which permits use, distribution and reproduction in any medium, provided the original work is properly cited, the use is non-commercial and is otherwise in compliance with the license. 


\section{INTRODUCTION}

\section{INNOVATION AND COMMENCEMENT OF BUSINESS ACTIVITY}

Contemporary popularity of a start-up as a form of commencing business activity is largely due to the fact that man is a creature who is prone to daydreaming and can live his dreams for quite a long time. Powerful corporate organizations such as the American Amazon Group are known for their policy of acquisition of interesting start-ups and their successful development. A well-known example of such acquisition in Poland was Ivona, the company involved in production and marketing of Text to Speech virtual servers. Acquired enterprise has been transferred into R\&D activity of Amazon in Gdańsk. Building new ventures in a mature economic environment is far more difficult, because of the extensive corporate management regulations and the extended decision-making process. However, an even more significant factor is the lack of ability to suppress human ardour at a low cost. In a large corporation, where employees' earnings are higher than those of small business employees, the incentive to take business risks is much less than for small businesses fuelled by their owners' dream fuel.

Despite the huge popularity of this phenomenon, its recognition in the cognitive frame is quite complicated. It is not easy to find features that clearly help distinguish a start-up from an ordinary enterprise, especially in the commercial and service industries, which include sports activities. Steve Blank and Bob Dorf define a start-up as a temporary organization that looks for a scalable, repetitive and profitable business [1: 34]. The authors of the book, popular in the United States, support the Model Customer Development method, claiming that products created by company founders, who contact their clients as soon as possible, are more successful. On the other hand, enterprises related to products transferred to organizations responsible for sales and marketing, which are only slightly involved in development works, more likely end in disaster [1]. In their opinion, the combination of the customer development model and agile project management methodology increases the chances of success for a new product and a new company, while reducing the need for capital, eliminating the waste of time, energy and effort [1].

Diferentia specifica in the definition of a start-up is therefore conducting an economic experiment in conditions of high risk and an unstable market. One could even say in some cases - in the conditions of market creation. The last refer to the situation when a completely new product is created. An experiment is both the subject of such activity and the activity itself, in particular the way it is conducted. Therefore, we are dealing with a phenomenon located on the limit between science and entrepreneurship. Therefore, innovation should be broadly understood as the fundamental feature of a start-up, which in the regulatory environment acts as a conceptual link between the area of science and the area of entrepreneurship.

It should be noted that, although innovation is a necessary feature of a start-up, innovation itself could be successfully used by other types of enterprises. The need to implement new, original solutions may result from the desire to explore the market or the need to search for other markets. Such situations most often accompany economic and social crises, which force people to take on new challenges. The current times of crisis are therefore the best moment to remember the need to experiment and search for innovative solutions.

It will be shown further of several examples that innovation might be regarded as an important enhancement of commercial activity also in sport. However, there are some limits to sport innovative activity, which are more clearly visible than in other areas of commerce. One of them - related to the regulatory environment will be discussed in this paper. 


\section{THE CONCEPT OF INNOVATION}

While understanding the start-up in social sciences, including legal doctrine and normative acts, is not widely recognized, the concept of innovation has a fairly broad theoretical and legal foundation. The reason for this is, above all, noticed quite a long time ago, by various public structures, the need to provide funds to entities interested in conducting research and development activities focused not only on profit, but also on some scientific and technological progress. Today, the most significant expression of this tendency was to make innovation the key theme of the European Union's 2020 strategy [2].

Adoption of innovation is, therefore, crucial for defining the phenomenon of start-up, not only for theoretical reasons consisting in proximity to the concept of experimentation, but also can be considered necessary for practical reasons, due to the fact that it is a lock pick that opens the way to obtaining different type of public funds.

Acquiring appropriate financial resources is, in turn, crucial for the possibility of establishing and developing a new company. It is worth noting that the opportunities offered by the public sector are not limited to increasing revenues, by raising funds for operations, but also relate to cost savings, mainly due to lowering public levies.

\section{THE CONCEPT OF INNOVATION IN THE REGULATORY ENVIRONMENT IN POLAND}

The importance of innovation and its support can be demonstrated by the fact that the Polish legislator mentions it in over a thousand legal acts. At the same time, since 2008 the Polish law has a definition of innovation regulated in the Act on certain forms of supporting innovative activity [3]. The existing legal definition, although it is a phenomenon of a legal language, is rarely used in the jurisprudence of tax authorities or in the application of state aid law. It is worth quoting its sound because it can pose many problems. Although the concept of innovation is most often understood functionally, taking into account the principles in force in a given legal system and the purpose of a particular regulation, literal interpretation is still of paramount importance in the Polish legal system. Against the background of the statutory definition in the context of other sources of understanding this concept, it is also clear that innovation can be understood narrowly or broadly in both the subject and subject plane.

In the above-mentioned Act, it was defined as an activity consisting in the development of a new technology and launching the production of new or significantly improved goods, processes or services on its basis. Undoubtedly, this is a very general definition, and considering its application for the purpose of obtaining various types of public benefits, the lack of detailed analysis may cause significant risk for the potential beneficiary. The basic premise for recognizing activities as innovative is the novelty element related to the phenomenon of technology, i.e. the method of conducting the production process. It should be noted that the modern understanding of technology in various areas of life is rather broad, due to the dynamics of economic phenomena. Therefore, most often technology is not treated narrowly as a field of technology leading to the production of goods, but also as a system of knowledge, techniques, qualifications, expert knowledge and organization, used to produce, sell, and use goods and services that meet economic and social demand [4]. The above understanding of technology corresponds to the intention of the legislator, who, defining it partly idem per idem, refers to the results of development works or the results of application research, defined in the Act on higher education [5], which all the above-mentioned elements include. It can be said with certainty that neither the novelty element nor the technology reference are detailed enough to draw up a road map for the entrepreneur who would like to benefit from the title of innovative activity. An additional 
complication may be the use by the legislator of the terms "development" and "starting [...] production". While the first of them can be identified as a typical activity in the area of research and development, "launching" is a very vague wording and not entirely consistent with business processes. It refers more to setting the production chain in a physical sense than to setting the market in terms of marketing. The importance of starting production is complicated in the case of services. While in the case of goods it could be narrowed down to the physical start of production, in the case of services it is rarely possible to distinguish such an activity. Undoubtedly, the goal of supporting innovative activity is generally understood as economic development; therefore, innovative activity should refer not only to the stage of creating an innovative product or service, but undoubtedly also to bringing it to the market, which in turn is associated with technological novelty in the area of processes, organization and marketing.

The development of the third edition of the so-called Oslo Manual, prepared under the joint aegis of the OECD and the European Commission (Eurostat), was the result of a three-year cooperation with the OECD Working Party of National Experts on Science and Technology Indicators (NESTI) and the Working Group Eurostat for Statistics on Science, Technology and Innovation (WPSTI), as well as a number of external experts. Using the Oslo Manual is justified, among others, by the fact that the majority of provisions on public and legal benefits for innovative projects derive from European regulations. An example would be the provisions on so called IP Box tax benefits, which do not significantly reflect the international consensus expressed by the OECD in the BEPS Action Plan [6]. According to the authors of the above study, innovative activity includes all scientific, technical, organizational, financial and commercial activities that actually lead or are intended to lead to the implementation [7] of a new or significantly improved product understood as a product or service. This also applies to the process as well as the new marketing method or new organizational method in business practice, as well as the organization of the workplace or relations with the environment [7].

It should be noted that the above definition of the Polish Act on certain forms of supporting innovative activity is literally narrower, as it does not include innovations that include new marketing methods. The Polish legislator explicitly mentions, "launching [...] production" of a product or service, while marketing activities are activities accompanying the launch of a product or service on the market, so it is difficult to link them directly to the production. A particularly cautious approach should therefore be taken for this type of innovation. The authors of the Oslo Manual indicate in their study that innovation can be understood narrowly as activities directly related to product research and development, and more broadly. They emphasize that innovations cover a number of activities that do not fall within the scope of research and development activities, such as late stages of development activities for the needs of the pre-production phase, production and distribution, as well as development works with a lower degree of novelty, supporting works such as training and market preparation, as well as development and implementation activities related to innovation, such as new marketing methods or new organizational methods that are not included in product or process innovation [7].

An unquestionable advantage of the approach presented in the Oslo Manual is a clear specification of the goal of innovative activity, which is implementation of innovative solutions. Its existence can be recognized when a new product is introduced to the market. New processes, marketing methods or organizational methods are implemented when they are actually used in the company's operations [7]. In relation to the definition from the Polish act, the centre of gravity is clearly shifting from pursuit of implementation to achieving the economic goal. Simply starting production can only mean building the company's warehouse resources and ultimately fail to bring the expected effect of generating value added. 
The difference in statutory definition and Oslo Manual regulation constitutes a potential risk generator, in particular for all kind of social innovations, which may be developed in sport as commercial activity. It may be a limit of access to public financial resources, in example state aid, and tax benefits, which depends on recognition of activity as innovative.

\section{TYPES OF INNOVATIVE ACTIVITIES}

Undoubtedly, it is also worth paying attention to the very clear classification of innovative activities adopted in consequence of the definition discussed above in the Oslo Manual. It develops and complements the broad definition of innovation. Four types of innovations are distinguished in the study: product innovations, process innovations, marketing innovations and organizational innovations [7].

The first type is product innovation, which is defined as the introduction of a product or service that is new or significantly improved in terms of its features or applications. This includes significant improvements in terms of technical specifications, components and materials, embedded software, ease of use, or other functional features. This is not only about products and services created based on new knowledge, but also those that are based on new applications or combinations of existing knowledge and technology. The feature of novelty, which I indicated at the beginning as a key to distinguishing innovative products, is understood as significant differentiation in its features or purpose from products previously manufactured by the company [7]. It is worth emphasizing here that the Oslo Textbook refers to the novelty feature of the company. On the other hand, the Polish legislator, by combining the definition of innovation with scientific research, refers to novelties in a global perspective. This approach can lead to numerous interpretation problems for new services. The Oslo Manual indicates that product innovation in the service sector can consist in introducing significant improvements in the way services are provided. For example, it may be about increasing the efficiency or speed of their provision, as well as adding new functions or features to existing services or introducing completely new services [7]. In this case, demonstrating the features of novelty, within the meaning of the Polish Act, if the service does not involve the use of new material elements can be very complicated.

Another type is process innovation defined as the implementation of a new or significantly improved production or delivery method. This category includes significant changes in technology, equipment or software. The goal of process innovations can be to reduce unit costs of production or delivery, increase quality, production or supply of new or significantly improved products [7]. An example of process innovation can be various types of automation, using new technical solutions such as robots. Delivery methods, on the other hand, relate to the company's logistics and include devices, software and techniques used to purchase means of production, allocate resources within the company or deliver final products [7]. Examples of such innovations include high storage systems and any new solutions for the packaging of goods. Unfortunately, the statutory definition discussed here, due to the rather unfortunate formulation of "process manufacturing", does not provide certainty whether this type of innovation, like product innovation, falls within the concept of innovative activity defined in the Act on certain forms of supporting innovative activity. If the phrase "processes" were grammatical to refer to the phrase "development" such doubt would probably not arise. Nevertheless, due to the fact that the result of production should rather be goods or services, and processes should be the reason for their emergence, the above formulation can also be considered a lapsus linguae. However, the doubt remains.

As I have already mentioned, we have a slightly clearer situation in the case of the fourth type of innovation, i.e. marketing innovation. The Oslo manual defines it as the implementation of a new marketing method involving significant changes in the design or product design or 
packaging, distribution, promotion or price strategy [7]. Therefore, it is about any changes in the sales process, and their essence should be to focus on better satisfying the needs of customers, opening new markets or new positioning of the company's product on the market to increase sales. This type of innovation can be described as "soft" because its basic physical manifestation is the emergence of a new concept or marketing strategy. In practice, this means the lack of "hard", technical or physical results of innovation, which in turn can cause a lot of room for more difficult discussion. This was probably the basic reason why the Polish legislator did not decide to include the phenomenon of marketing in the scope of the statutory definition in question.

This kind of innovation is also specific to social innovation in sport. As it was already mentioned that might constitute a challenge, in respect of access to public resources, by sport start-ups and other innovative enterprises.

The fourth type of innovation mentioned in the Oslo Textbook is the organizational innovation, which involves the implementation of a new organizational method in the principles of operation adopted by the company, in the organization of the workplace or in relations with the environment [7]. A special feature of organizational innovation in combination with other organizational changes in the company is the use of an organizational method that has not been used before. As an example, new practical principles can be identified to improve the learning process and knowledge sharing within the company [7]. Undoubtedly, a characteristic feature of organizational innovation as opposed to process innovation is its reference to the functioning of the enterprise in its entirety, and not only in the aspect related to the specific process of creating a product or service. The organization is a kind of metaprocess. In addition to the doubts raised above as to the scope of the definition of process innovations, it should also be noted that the legislator clearly requires demonstrating a direct relationship between such an innovation and a product or service, using the phrase "on its basis". Even if process innovation is an innovation within the meaning of the Act, and the meta-process can also be considered a process, demonstrating the relationship between organizational innovation and a product or service may not be easy.

\section{EXAMPLES OF INNOVATIVE ACTIVITIES IN SPORT}

The definition of innovation quoted above and a closer description of this phenomenon by reference to the types of innovation activities at first glance, to a small extent, matches activities in the field of sport. Undoubtedly, the easiest way to demonstrate innovation is when a new product or service is introduced to the market. The sports industry, which is based on traditional business models, is not an area where you can easily conduct economic experiments. Customers in this industry are accustomed to standards of behaviour, and changing these habits is not easy. However, this does not mean that there is no space for innovation in sporting activities and it is not worth running a start-up.

While product innovations can pose a challenge here, although it would not be true to say that they do not appear, especially in the field of sports equipment ${ }^{1}$, undoubtedly sports activities can be an excellent field for the development of various process as well as marketing and organizational innovations.

A great example of implementing innovation in sport is CityFit ${ }^{2}$, which built its business model on providing permanent access to sports infrastructure. The most important element of this model was enabling access to the facility without service, using electronic biometric

${ }^{1}$ Examples of innovative products in the sports equipment industry appear notoriously. One of the most interesting ones you can give is Blazepod, https://blazepod.com.pl/ [Accessed on 10.06.2020].

${ }^{2}$ https://cityfit.pl/ [Accessed on 10.06.2020]. 
readers $^{3}$ and electronically controlled partitions. Thanks to this, the entrepreneur could present clients an attractive offer, the costs of which were reduced due to the automation of a key process in this type of facility, i.e. sharing.

It is worth noting that innovation in CityFit was not a random phenomenon, but it was at the root of its character. The entrepreneur has implemented and expanded the communication system with clients through an application for mobile devices, and also created an innovative partner system for personal trainers .

Other interesting examples of innovations in sports activities appear in the area of standard training programs, sometimes referred to as McDonald's sports [8]. An example of a company that successfully implements innovative standardized training programs is an American company led by Phillip and Jackie Mills - les Mills ${ }^{4}$. It is an entity that licenses its training methods in seventy countries around the world. The innovation of their methods is based on the results of searching for the best methods of arranging physical movement and their standardization [9: 527]. Of the more than a dozen programs implemented and licensed on the basis of franchising, it is worth paying special attention to those that combine elements of traditional East Asian systems such as yoga or tai-chi and modern training systems such as Pilates ${ }^{5}$. Similarly, innovative features are manifested by the system inspired by Eastern martial arts and boxing ${ }^{6}$.

A certain hybrid of training system solutions and modern sports equipment is the solution of the American company Zwift ${ }^{7}$, which has developed plans for a new e-sports league that combines professional software for cycling, video games and monitoring physical activity $^{8}$. The goal of its creators is to use the growing popularity of e-sport and enthusiasm for a healthy lifestyle and cycling. Combining these three areas, the company reveals the unexplored potential of the sports services market, addressed to both people who prefer spending time at home as well as those who are inclined to physical activity and group competition.

\section{CONCLUSION}

The above examples illustrate the potential for implementing innovative solutions in the sports industry, which can undoubtedly also benefit from the public support to some extent. However, it is worth mentioning once again that the described above uncertainties of the regulatory system might be regarded as a serious risk factor and a limitation of access to public financing. Although sport enterprises have important innovative potential, there is definite lack of clear public stimulus in this area. That might be the reason why statistically technology companies, mainly from the IT and new technologies industries, are undoubtedly still a majority among start-ups.

This state of affairs may change to some extent as a result of the current experience with the Covid-19 epidemic, in particular those related to the closure of many public places, in particular sports facilities. Losses caused by the suspension of operations in these facilities may be an incentive to look for new solutions, especially that the awareness of the need to maintain mobility is now quite common and is the flywheel of the sports industry.

\footnotetext{
See https://cityfit.pl/trener/ [Accessed on 10.06.2020].

${ }^{4}$ https://www.lesmills.com/about-us/ [Accessed on 16.06.2020].

${ }^{5}$ System of Bodyballance https://zwierciadlo.pl/zdrowie/innowacje-przyszlosc-sportu [Accessed on 16.06.2020].

${ }^{6}$ System of Bodycombat https://zwierciadlo.pl/zdrowie/innowacje-przyszlosc-sportu [Accessed on 16.06.2020].

7 https://zwift.com/eu [Accessed on 16.06.2020].

8 https://www.branzafitness.com/14448-2/ [Accessed on 16.06.2020].
} 


\section{REFERENCES}

[1] Blank S, Dorf B. Podręcznik startupu [Startup manual]. Helion; 2013. Polish.

[2] Communication of EU Commission to the Parliament, Council and European Social and Economy Committee, and Committee of Regions, EU Strategy leading Project, The Union of Innovations, Brussels 6.10.2010 r. COM(2010) 546 final. SEC(2010) 1161.

[3] Article 2(1) indent 3 of Act on some forms of support for innovative activities. Journal of Laws $2008 \mathrm{Nr} 116$, item 730, consolidated text J Law 2019 item 1402. Polish.

[4] Sieńczyło-Chlabicz J. Komercjalizacja i transfer wyników badań naukowych i prac rozwojowych z uczelni do gospodarki. Komentarz - nowe regulacje. System Informacji Prawniczej Legalis [Commercialization and transfer of research and development results from universities to the economy. Comment - new regulations. Legalis Legal Information System]. Warszawa: Wydawnictwo C.H. Beck; 2019. Polish.

[5] Article 2(1) indent 9 of Act on some forms of support for innovative activities. Journal of Laws $2008 \mathrm{Nr} 116$, item 730, consolidated text J Law 2019 item 1402. Polish.

[6] The tax explanations of the Ministry of Finance of July 15, 2019. Polish.

[7] Oslo Manual, Principles of Gathering and Interpretation of Data Related to Innovation, Third Edition; 2005.

[8] Andreasson J, Johansson T. The new fitness geography: the globalisation of Japanese gym and fitness culture. Leisure Stud. 2017;36(3):383-394.

[9] Parviainen J. The standardization process of movement in the fitness industry: The experience design of Les Mills choreographies. Eur J Cultural Stud. 2011;14(5): 526-541. https://doi.org/10.1177/1367549411412202 